\title{
Correction to: Structural evaluation of masonry building damages during the April 24, 2014 Gökçeada earthquake in the Aegean Sea
}

\section{Caner Gocer ${ }^{1}$}

Published online: 8 May 2020

(c) Springer Nature B.V. 2020

\section{Correction to: Bulletin of Earthquake Engineering https://doi.org/10.1007/s10518-020-00833-z}

This erratum is published due to following errors noticed after publication:

\section{CORRECTION 1:}

Adding the following article to the reference list:

Saltogianni V, Gianniou M, Taymaz T, Yolsal-Çevikbilen S, Stiros S (2015) Fault-Slip source models for the $2014 \mathrm{Mw} 6.9$ Samothraki-Gökçeada earthquake (North Aegean Trough) combining geodetic and seismological observations. J Geophys Res Solid Earth 120(12):8610-8622

\section{CORRECTION 2:}

Adding the related article to the caption of Fig. 2 as a reference and editing the caption of Fig. 2 as follows:

Fig. 2 The focal mechanisms and locations of major earthquakes that occurred in the North Aegean since 1965 (Taymaz et al. 1991; Taymaz and Yolsal-Çevikbilen 2015; Saltogianni et al. 2015)

Publisher's Note Springer Nature remains neutral with regard to jurisdictional claims in published maps and institutional affiliations.

The original article can be found online at https://doi.org/10.1007/s10518-020-00833-z.

Caner Gocer

gocercaner@gmail.com

1 Department of Architecture, İstanbul Technical University, 34367 İstanbul, Turkey 